\title{
Os juízes, a lei e a Justiça
}

Judge, law and Justice

Eros Roberto Grau'

01. Fiz de propósito! Digitei juízese leiem minúsculas e Justiça com J maiúscula. Isto porque, como afirmarei quase ao fim desta minha expansão literária, vinculados pelo dever de aplicar as leis e a Constituição, os juízes não a fazem. Justiça é lá no Céu!

Tenho sistematicamente me repetido, sempre a afirmar: (i) que são distintas a interpretação e a aplicação da Constituição e das leis e (ii) que os juízes não legislam, hão de limitar-se a decidir quando e como as normas da Constituição e das leis se aplicam.

Lembrando um poema de um gaúcho como eu, Augusto Meyer --- de quem fui amigo cá na Terra e, tenho certeza, reencontrarei lá no Céu --- repito-me como se mascasse e remascasse a minha raiva chewing gum.

Não, raiva não! Pena dos que ignoram a nossa Constituição. Qualquer um de nós pode tentar interpretá-la, mas apenas os juízes efetivamente a aplicam, em suas decisões. Qualquer cidadão, inclusive advogados --- como voltei a ser após ter passado alguns anos lá em Brasília, naquele tribunal --- pode comentá-la, mas de jeito nenhum alterá-la. Mas de jeito nenhum! --- como me diz de vez em quando meu velho camarada Leopoldo Rassier, agora também lá no Céu!

02. Começo relembrando que interpretação e aplicação da Constituição e das leis não se confundem. Com o tempo e a idade, é-me permitido reproduzir, em apertada síntese, o quanto afirmei em meu Por que tenho medo dos juízes².

Interpretação e aplicação não se realizam autonomamente. O intérprete autêntico --- isto é, o juiz --- discerne o sentido do texto a partir e em virtude de um determinado caso.

Assim é porque a interpretação do direito praticada pelos juízes consiste em concretar a lei em cada caso, isto é, na sua aplicação. Quando os juízes a praticam --- note-se bem, apenas eles a podem praticar ---, interpretação e aplicação consubstanciam um processo unitário, superpõem-se.

A interpretação do texto de lei operada pelo advogado, pelo promotor público e por outros mais que não sejam membros do Poder Judiciário não vincula ninguém. Cessa em si mesma, nada tem a ver com a efetiva aplicação da Cons-

$1 \quad$ Advogado. Professor Titular aposentado da Faculdade de Direito da USP, foi Ministro do STF.

29 9a edição, Malheiros Editores, São Paulo, 2018; Pourquoi j'ai peur des juges (Éditions Kimé, Paris, 2014) e Das Verhältnis der Richterschaft zum Recht (trad. Volkhart Hanewald, Nomos, Baden-Baden, 2019). 
tituição e das leis. Compõe-se no discurso jurídico. Apenas o intérprete autêntico pronuncia o discurso do direito.

Discurso do direito é o discurso prescritivo produzido pelos juízes e tribunais autorizados a dizê-lo. O jurídico, por outro lado, é um conjunto de outros discursos: o dos advogados, o dos professores de direito e o dos cidadãos, por exemplo.

Este ponto é essencial: quem dele não tem plena consciência tropeça nos próprios pés, ultrapassa os limites da racionalidade.

03. Mas há mais, a distinção entre norma jurídica e norma de decisão.

A norma jurídica é o resultado da interpretação. Interpretação não apenas do texto escrito e da realidade, no momento histórico no qual se opera a interpretação, mas também dos fatos. A interpretação judicial visa à solução de casos concretos. Solução que se opera mediante a obtenção de uma norma de decisão. Em suma, a norma de decisão é a norma jurídica aplicada a um caso concreto.

Desde aí, retornando à obviedade que apontei linhas acima, reafirmo que apenas os juízes aplicam a Constituição e as leis. Apenas eles pronunciam o discurso do direito, expressivo de quando e como os preceitos da Constituição e das leis aqui ou ali se aplicam.

04. A multiplicidade do tempo permite que eu volte ao passado para relembrar que desde a Constituição de 1946 --- vigente quando frequentei a Faculdade como aluno --- entendia-se que, como hoje diz o artigo $2^{\circ}$ da nossa Constituição, são Poderes da União, independentes e harmônicos entre si, o Legislativo, o Executivo e o Judiciário.

O Poder Legislativo cria, produz as leis e --- quando convertido em Poder Constituinte --- as emendas constitucionais. O Poder Executivo e todos nós, cidadãos e membros do Legislativo, do Executivo e do próprio Judiciário, observamo-las e cumprimo-las. O Poder Judiciário, cogitando as condutas de todos nós, inclusive dos seus membros, decide a respeito da observância e da correta aplicação do todo que a Constituição e as leis compõem. Esse é o quadro de deveres e competências que a nossa Constituição define.

Quanto aos juízes, estes definem normas de decisão a partir de normas jurídicas extraídas de textos normativos e da realidade, no momento histórico no qual se opera sua interpretação, sempre considerando, em cada caso, os fatos que a ele correspondem.

Um ponto fundamental, pois: os juízes podem/devem produzir normas de decisão extraídas de textos normativos, mas nos seus limites, sem usufruírem da liberdade de criar normas jurídicas que neles não estejam contidas.

05. Não gozam do poder de produzir normas de decisão ao se depararem com lacunas normativas. 
O modo de ser, o desempenho de suas funções pelos juízes, não pode exceder o quanto dispõem os textos normativos. Qualquer intérprete estará, sempre, permanentemente por eles retido. Do rompimento dessa retenção pelos intérpretes autênticos, os juízes, resultará a subversão do texto. Eis a primeira razão pela qual nego a chamada discricionariedade judicial.

Além disso, outra razão me impele a repudiar o entendimento de que o intérprete autêntico possa exercer essa discricionariedade. Isso porque, ao intérprete autêntico, não é atribuída a formulação de juízos de oportunidade. A eles compete unicamente a expedição de juízos de legalidade. Ainda que não seja meramente a boca que pronuncia as palavras da lei, a função --- dever-poder --- dos juízes está contida nos lindes da legalidade e da constitucionalidade. Interpretar o direito é formular juízos de legalidade. A discricionariedade é exercitada em campo onde se formulam juízos de oportunidade (= escolha entre indiferentes jurídicos), exclusivamente quando uma norma jurídica tenha atribuído à autoridade pública a sua formulação.

O que algumas vezes se tem denominado discricionariedade judicial é o poder de criação de norma jurídica que o intérprete autêntico exercita formulando juízos de legalidade, não de oportunidade. A distinção entre tais juízos encontra-se em que o juízo de oportunidade comporta uma opção entre indiferentes jurídicos, ao passo que o juízo de legalidade é atuação, embora desenvolvida no campo da prudência, que o intérprete autêntico desenvolve atado, retido, pelo texto normativo e pelos fatos.

A interpretação é expressão de uma manifestação constitutiva, que envolve uma decisão. Essa decisão é assumida mediante a formulação de um juízo de legalidade, não de um juízo de oportunidade (= discricionariedade). Não obstante, a doutrina insiste no equívoco de confundir discricionariedade (juízo de oportunidade) com a liberdade de pensar, própria da natureza do homem. O que me leva a repudiar --- lastimavelmente isolado no campo da chamada doutrina do Direito --- a conversão da discricionariedade em uma como que técnica alternativa da legalidade.

06. Permitam-me insistir em que os juízes não legislam. Devem limitar-se a decidir quando e como os mandamentos da Constituição e das leis se aplicam. Ainda que ao formularem juízos de legalidade exerçam sua liberdade de pensar, seus pensamentos são livres somente na moldura da legalidade.

Die Gedanken sind frei --- os pensamentos são livres --- como diz uma velha canção alemã do início do Século XIX. No exercício de sua função, no entanto, o pensamento dos juízes é livre na moldura da legalidade. Não para além dela. Os textos normativos limitam-se a estabelecer uma moldura limitadora das possibilidades de correta concretização do direito. A construção da norma de decisão (isto 
é, a decisão) se dá dentro dessa moldura, decorrendo também da realidade, pois é ela que confere sentido ao texto interpretado.

Referindo um exemplo bem marcante, mais de uma vez tentei deixar isso bem claro. Nosso Código Penal define como ultraje público ao pudor, em seu artigo 233, a prática de ato obsceno em lugar público, ou aberto ou exposto ao público.

Daí que uma mulher que fosse à praia ou à piscina com um maiô de duas peças, cavado, corria o risco de ser importunada pela autoridade policial pela prática desse ultraje. Mas se hoje uma mulher for à praia ou à piscina de topless --- não a mesma mulher, evidentemente! --- ela não será incomodada pela autoridade policial.

O texto é o mesmo, mas a norma que dele se extrai é outra. Isto porque o significado válido dos textos normativos é variável no tempo e no espaço, histórica e culturalmente, da sua interpretação e da realidade, no momento histórico no qual se opera a interpretação, resultando na produção, pelo intérprete autêntico, das normas jurídicas a serem ponderadas para solução deste determinado caso.

07. Insisto em que a interpretação judicial não é livre, encontra limites na moldura da norma jurídica. Tentando deixar isso bem claro, lembro um recente julgamento do Supremo Tribunal Federal, findo há poucos dias. Mais, recorro a um texto publicado na edição de 22 deste mês, novembro de 2019, n'O Estado de São Paulo. Texto que escrevi lembrando do voto que proferi como relator do habeas corpus 84.078-7 em 2009, quando eu era membro daquele tribunal lá de Brasília, o STF.

Pensando e repensando, relembrando meu amigo Augusto Meyer e mascando e remascando-o --- agora evidentemente chewing gum --- mais do que relembrando-o, passo a transcrevê-lo. Pedindo absolvição ao leitor de agora por repetir trechos do que escrevi linhas acima...

08. Ao me referir aos juízes, desembargadores e ministros dos nossos tribunais, seguidamente me repito, lembrando um texto de Sartre a propósito da conduta do garçom que executa uma série de gestos solícitos para atender ao cliente. Os garçons cumprem seu papel no café ou restaurante no qual trabalham sendo gentis inclusive e mesmo em relação a clientes que detestam.

Assim é o juiz. Cumpre o papel que a Constituição Ihe atribui. Não é perpetuamente juiz. Mas, enquanto juiz, deve representar o papel de magistrado, nos termos da Constituição e da legalidade. Não o que é (e pensa) ao cumprir outros papéis, quais os de artesão ou jardineiro, por exemplo. Poderão então prevalecer os seus valores. Enquanto juízes, contudo, hão de se submeter à Constituição e às leis.

O que me traz agora a escrever este texto é o recente julgamento das ADC 43, ADC 44 e ADC 54, o Supremo Tribunal Federal recuperando e reafirmando o quanto decidiu em 2009, no julgamento do habeas corpus 84.078-7. 
Outro é o meu sentimento como cidadão, distinto do que dispõe a Constituição, que estabelece, no seu artigo $5^{\circ}$, inciso LVII, que ninguém será considerado culpado até o trânsito em julgado de sentença penal condenatória. E o inciso LXI desse mesmo artigo $5^{\circ}$, por outro lado, aplica-se não ao cumprimento de pena, mas à prisão preventiva em flagrante delito ou por ordem escrita e fundamentada da autoridade judiciária competente.

A distinção entre ambos é evidente: o primeiro --- inciso LVII --- diz respeito à prisão preventiva, o segundo --- inciso LXI --- ao cumprimento de pena.

Mas, o preceito estabelecido pelo artigo 283 do Código de Processo Penal, que autoriza a prisão por ordem escrita e fundamentada da autoridade judiciária competente, não é suficiente para justificar a execução antecipada da sentença. Preceitos constitucionais não podem ser expurgados por leis ordinárias.

A circunstância de ter procedido como um "garantista" durante o tempo no qual exerci a magistratura --- e não como "consequencialista", designação hoje atribuída aos juízes praticantes de direito alternativo --- traz-me serenidade.

Não me cansarei de repetir que vamos à Faculdade de Direito aprender direito e não justiça. Uma indagação de Bernd Rüthers é de todo aplicável aos nossos tribunais e juízes: pode um Estado, pode uma democracia existir sem que os juízes sejam servos da lei? A resposta é negativa, dado que a independência judicial é vinculada à sua fiel obediência ao direito positivo.

Pequenos trechos extraídos do voto que proferi no julgamento do habeas corpus 84.078-7, no STF, dizem o quanto desejo aqui enfatizar.

A ampla defesa não pode, em face do que dispõe a nossa Constituição, ser visualizada de modo restrito. Engloba todas as fases processuais, inclusive as recursais de natureza extraordinária. A execução de sentenças após o julgamento do recurso de apelação significa restrição do direito de defesa. Uma assertiva de um meu amigo de verdade, o Ministro Evandro Lins, tudo sintetiza: Na realidade, quem está desejando punir demais, no fundo, no fundo, está querendo fazer o mal, se equipara um pouco ao próprio delinquente.

Nas democracias, mesmo os criminosos são sujeitos de direito, não meros objetos processuais. $\mathrm{E}$ as singularidades de cada infração penal somente podem ser plenamente apuradas quando, nos termos do que define 0 artigo $5^{\circ}$, inciso LVII da nossa Constituição, transitada em julgado à condenação de seus autores.

Não fosse assim, melhor seria que os magistrados abandonassem seu ofício e saíssem por aí, cada qual com o seu porrete, arrebentando a espinha e a cabeça de quem os contrariar. Cada qual com o seu porrete! Cada um por si e a Constituição contra... 
A lição do profeta Isaias que se lê na Bíblia $(32,15-17)$ basta-me por tudo: $O$ direito habitará no deserto e a justiça morará no vergel. $O$ fruto da justiça será a paz, e a obra da justiça consistirá na tranquilidade e na segurança para sempre.

É certo que, enquanto cidadãos, gozamos da liberdade de falar como quisermos, mesmo correndo o risco de afirmar o que não tem sentido. A respeito da chamada "prisão em segunda instância", por exemplo, há até quem chame os ministros do STF de "centauros com quatro patas de cavalo".

Essa liberdade não deveria ser excedida mesmo pelos que não frequentaram Faculdades de Direito. Leio aqui e ali afirmações inconcebíveis, tal e qual a de que as regras jurídicas podem elidir os princípios jurídicos --- vale dizer regras-princípio. Mais, ignorância total do fato de que nossa Constituição, como afirmei linhas acima, nos incisos LVII e LXI do seu artigo $5^{\circ}$, distingue a prisão preventiva do cumprimento de pena. E sobretudo ironias de que o Supremo Tribunal Federal solta presos que não foram condenados em última instância para beneficiar outros.

Sei bem que uns e outros desejam fazer justiça com as próprias mãos, mas não me cansarei de reafirmar que nem mesmo os juízes fazem justiça. Pois são vinculados pelo dever de aplicar as leis e a Constituição. Justiça é lá no Céu!

Permito-me por fim lembrar que, tal qual dispõe o artigo 60 , $\S 4^{\circ}$, IV da nossa Constituição, não será objeto de deliberação a proposta de emenda tendente a abolir direitos e garantias individuais. Percebem? Somente uma nova Assembleia Constituinte poderá impor o cumprimento de sentença condenatória a partir de condenação em segunda instância!

09. A quem me perguntasse se tenho alguma crítica a fazer àquele tribunal ao qual pertenci, eu diria que nenhuma.

A ele, nenhuma crítica. Limitar-me-ia a lembrar de um episódio que vivi em 2006. Foi a Brasília um juiz da Corte Constitucional francesa e o Jobim, então presidindo o nosso Supremo, incumbiu-me de recebê-lo.

Participamos de uma exposição a respeito de nossos tribunais, jantamos em um restaurante e em janeiro seguinte, em Paris, ele me recebeu em seu tribunal. Depois saímos para almoçar, caminhamos até um restaurante pela Avenida da Opera e, de repente, após uma caminhada de uns duzentos metros, coisa assim, ele me disse: Veja como ninguém me conhece! Posso livremente andar pela rua, sou apenas um juiz, um magistrado! Não um ator da televisão!.

Calei-me. Mas aqui, hoje, quando me chamam de ministro, respondo sempre que não sou eu, aquele de lá é meu sósia! Não faz mal, um dia, lá no Céu, sorrirei para todos! 